Boak, George ORCID:

https://orcid.org/0000-0002-4489-3096, Sephton, Ruth, Hough, Elaine and ten Hove, Ruth (2017) Quality improvement in physiotherapy services. International Journal of Health Care Quality Assurance, 30 (5). pp. 424-435.

Downloaded from: http://ray.yorksj.ac.uk/id/eprint/1999/

The version presented here may differ from the published version or version of record. If you intend to cite from the work you are advised to consult the publisher's version: https://doi.org/10.1108/IJHCQA-05-2016-0066

Research at York St John (RaY) is an institutional repository. It supports the principles of open access by making the research outputs of the University available in digital form. Copyright of the items stored in RaY reside with the authors and/or other copyright owners. Users may access full text items free of charge, and may download a copy for private study or non-commercial research. For further reuse terms, see licence terms governing individual outputs. Institutional Repository Policy Statement

\title{
RaY
}

Research at the University of York St John

For more information please contact RaY at ray@yorksj.ac.uk 


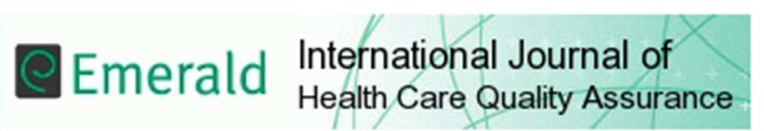

\section{Quality improvement in physiotherapy services}

\begin{tabular}{|r|l|}
\hline Journal: & International Journal of Health Care Quality Assurance \\
\hline Manuscript ID & IJHCQA-05-2016-0066.R2 \\
\hline Manuscript Type: & Original Article \\
\hline Keywords: & Quality improvement, Process improvement, Healthcare, Systems change \\
\hline \multicolumn{2}{|c}{} \\
\end{tabular}

SCHOLARONE $^{\text {It }}$

Manuscripts 
Quality improvement in physiotherapy services

Author 1

Name: George Boak

Qualifications: MSc, MA, PhD

Job title: Senior Lecturer in Leadership and Innovation

Department: York Business School

Institution: York St John University

Town/City: York

Country: United Kingdom

Telephone: 01904624624

e-mail: g.boak@yorksj.ac.uk

Author 2

Name: Ruth Sephton

Qualifications: Graduate Diploma Physiotherapy, MSc Physiotherapy

Job title: Consultant Musculoskeletal Physiotherapist

Department: Physiotherapy

Institution: 5 Boroughs Partnership NHS Foundation Trust

Town/City: Warrington

Country: United Kingdom

Telephone: 01512443465

e-mail: ruth.sephton@5bp.nhs.uk

Name: Elaine Hough

Qualifications: MSc Health Sciences, BSc Physiotherapy

Job title: Consultant Physiotherapist

Department: Physiotherapy

Institution: 5 Boroughs Partnership NHS foundation Trust

Town/City: St Helens and Whiston

Country: United Kingdom

Telephone: 01744621688

e-mail: dwgie@hotmail.com

Name: Ruth ten Hove

Qualifications: MSc MCSP

Job title: Head of Development and Research

Institution: Chartered Society of Physiotherapy

Town/City: London

Country: UK

Telephone: 02073147853

e-mail: tenhover@csp.org.uk

Corresponding author: George Boak

Corresponding Author's Email: g.boak@yorksj.ac.uk

Acknowledgments: Many people contributed valuable time and information to this research. The authors thank in particular: Victoria Dickens, Andrea Evans, Ruth Heaton, Keith Mills, Judith Neilson, Annalisa Newson, Sivaraj Shanmugam and Laura Williams. 


\section{Structured Abstract}

Purpose: To evaluate a process change in physiotherapy services and to explore factors that may have influenced the outcomes.

Design/methodology/approach: Multiple case study: information was gathered from eight physiotherapy teams over 24 months.

Findings: The process change was successfully implemented in six teams. It had a clear, positive effect on service quality provided to patients in three teams. Whilst quality also improved in three other teams, other issues make changes difficult to assess. Suggestions are made as to factors that enabled the process change to be effective.

Research limitations/implications: Findings are based on results achieved by only eight English teams.

Practical implications: This process change may be appropriate for other teams providing physiotherapy or other therapies if attention is paid to potential enabling factors, and a learning approach is adopted to designing and introducing the change.

Originality/value: This is the first process change longitudinal study in therapy services.To the best of our knowledge, no other longitudinal study of this process change in therapy services has been published.

Keywords: Quality improvement; Process improvement; Healthcare; Systems change.

Article Classification: Research

Received $12^{\text {th }}$ May 2016

Revised $14^{\text {th }}$ November 2016

Accepted

\section{Introduction}

There is pressure on healthcare service staff throughout the developed world to cope with rising demand and constrained funds (WHO, 2009). Process improvement (Health Foundation, 2013; Porter and Lee, 2013), quality improvement (Gauld et al., 2014) and Lean management (Jones and Mitchell, 2006) have been used to change systems, improve value and reduce waste. There are claims about methodological effectiveness (Hwang et al., 2014; Mazzocato et al., 2010), although some commentators voice doubts about how easily these approaches can be applied to healthcare (Burgess and Radnor, 2013; McIntosh et al., 2014; Young and McClean, 2009).

Our aim is to examine how one particular process improvement was attempted in National Health Service (NHS) musculoskeletal (MSK) physiotherapy services. This was part of a larger study, where representatives from 11 MSK physiotherapy teams in north-west England agreed to carry out process improvements in their services and to share information with colleagues. The Chartered Society of Physiotherapy (CSP) supported the projects by providing information about process improvements in physiotherapy services elsewhere and, where relevant, provided advice specific to a particular service's needs. The improvements that staff in 11 services decided to implement depended on their individual circumstances, including perceptions of patient needs, service pressures, resources and the impact of other changes. 
We focus on a change that staff in eight services attempted to introduce; i.e., reduce waiting times for treatment and reduce wasted resource caused by patients not attending appointments (DNA). This resource would then be used more productively to ensure good patient care.

The availability of routine MSK physiotherapy service data in the NHS is limited (Dorning and Bardsley, 2014), but recent survey results (CSP, 2013), indicate that it is not unusual for service staff to be faced with increasing demand and pressures on staffing, and that these factors may lead to longer waiting times before a patient is able to see a therapist. Patient waits for therapy are related to service quality, as waits may prolong discomfort and lead to deterioration in patients' condition, and longer periods in treatment (CSP, 2009). To date, only a few case studies show how physiotherapists have been able to change their systems and processes to improve their services (Amlani, 2011; Boak et al., 2015; Harding, 2011; Robinson, 2011). None has focused on the specific change introduced by these services.

\section{Improving processes in healthcare}

Methods used in manufacturing organisations to improve systems and processes, and to reduce waste have been introduced in healthcare. These methods are variously described as process improvement (DH, 2011; Health Foundation, 2013; Kaplan and Porter, 2011; Locock, 2003; NHS III, 2005), quality improvement (Aveling et al., 2012; Gauld et al., 2014; Gijo et al., 2013) and Lean management (Brandao de Souza, 2009; Drotz and Poksinska, 2014; Hwang et al., 2014; IHI, 2005; Jones and Mitchell, 2006). There are broad similarities between these approaches (Walshe, 2009). Process improvement is concerned with analysing and redesigning healthcare systems and processes to make them more effective and efficient (Locock, 2003; NHS III, 2005). Quality improvement focuses on value to customers - in healthcare, a key aspect is better outcomes for patients (Batalden and Davidoff, 2007) - and waste reduction (Gijo et al., 2013). Lean is based on identifying and producing services and products that customers value, while eliminating waste (Joosten et al., 2009). Process analysis and process change - key process improvements - are central elements (Mazzocato et al., 2010). Lean in manufacturing is designed to be a system-wide approach, but in healthcare Lean may focus on specific techniques (Waring and Bishop 2010) or be 'primarily implemented as a process improvement approach' (Drotz and Poksinska, 2014, p. 179) or be applied in a fragmented, rather than a systemic, way (Burgess and Radnor, 2013).

Radnor et al., (2012, p.364) report 'growing evidence of the potential impact on quality, cost and time' that process improvement projects have in healthcare, with tangible outputs such as 'reduction in waiting times, increases in quality through a reduction of errors, reduction in costs, as well as intangible ones such as increased employee motivation and increased customer satisfaction'. Although process and quality improvements often appear to emphasise tools that can be applied to solve problems in several contexts (Al-Balushi et al., 2014), studies indicate that applying these tools in healthcare settings is not straightforward (Drotz and Poksinska, 2014; Walshe, 2007). Some recent work in this area argues the need to understand the ways in which approaches are adopted and implemented in specific social contexts (Joosten et al., 2009; Khatami and Rosengren, 2015; Langley and Denis, 2011; Øvretveit, 2004; Powell et al., 2009; Waring and Bishop, 2010). Walshe (2007, p. 58) argues it is important to 'unpick the complex relationship between context, content, application and outcomes, and to develop a necessarily contingent and situational understanding of 
effectiveness'. In physiotherapy, research into a new assessment tool concluded there was value in exploring 'situated understanding', as healthcare professionals do not passively accept and apply clinical knowledge, but 'engage in the active interpretation and reconstruction of its local validity and usefulness' (Sanders et al., 2014, p. 97).

There is an evident need to engage clinicians if process changes are to be successful (Abdallah, 2014; Gollop et al., 2004; Powell et al., 2009). Process improvement approaches often advocate that practitioners who deliver services should be involved in decisions about how to change them (Locock, 2003; Sanders et al., 2014.). Change studies in healthcare note that individual perspectives on proposed changes may be influenced by, among other things, perceived motivation behind the change and that, in particular, clinicians may be suspicious about changes they perceive to be managerialist (Gollop et al., 2004; Ham et al., 2003; Young and McClean, 2009).

Common areas for process improvement in healthcare concern patient waiting times and reducing scheduled appointments where patients do not attend (DNA). Waiting times are a quality element (Appleby et al., 2014; Thorlby and Maybin, 2010) and a focus for analysis and improvement in healthcare (Foote et al., 2004, Gijo et al., 2013, Lodge and Bamford, 2007). In physiotherapy, as in other healthcare areas, shorter waiting times may lead to improved outcomes for patients (Amlani, 2011; CSP, 2009; Harding, 2011; Robinson, 2011). DNAs are an obvious waste in healtheare systems. In 2004, the UK NHS Modernisation Agency included 'Avoid unnecessary follow-ups' among ten recommended high impact changes, noting that:

Each year in the NHS there are 37 million 'followup' [sic] appointments where patients are asked to return to hospital to have their progress checked, to undergo tests, or to get test results. A significant proportion of these follow-up visits are clinically unnecessary, create inconvenience and anxiety for patients and waste valuable resources. 75\% of all outpatient 'Did Not Attends' (DNA) are for follow-up appointments ... There are more than four million follow-up DNAs per annum, which cost the NHS more than $£ 100$ million a year (p. 43).

Young and McClean (2009, p. 382) described this recommendation as a 'classical Lean elimination of waste'. In physiotherapy, a small number of single organisation case studies focus on DNAs (Clews, 2013; El-Tantawy et al., 2000; French et al., 2005; Harding, 2011). Attempts to change healthcare systems often require willing healthcare professionals, patients and other stakeholders (Sanders et al., 2014). Where a reduction in DNAs is sought, a change in patient behaviour is a key factor. Behavioural economists attempt to understand and influence choices made by patients and the public in healthcare areas such as public health (Loewenstein et al., 2012); diet and obesity (Liu, 2014) and heart disease prevention (Holt, 2010). Ideas drawn from social influence theory have attempted to reduce DNAs in general practice: Martin et al., (2012) tested small changes in communication with patients about appointments and found that - after some adjustment to the methods - the changes reduced DNAs.

To summarise, there are claims about process improvement methods in healthcare, but studies urge caution in applying methods as tools universally, arguing that context is important, and, therefore, a contingent and situational understanding is needed to improve services. In particular, it is usually important to engage clinicians in improvement processes. Depending on their nature. It may also be important to achieve willing behaviour change by patients - an area that behavioural economists have studied. Two common areas for process 
improvement - both involving changes in behaviour by clinicians and patients - are reducing waiting times, and reducing DNAs. Both can represent difficulties for physiotherapy services.

\section{Methodology}

We aimed to assess the attempts to change physiotherapy services provided to patients, and therefore our study is evaluation research (Robson, 2011). As a realistic evaluation, we sought to identify change effects, causal mechanisms leading to effects and the contextual elements that may have affected the outcomes (Pawson and Tilley, 1997). We bore the Mazzocato et al., (2010, pp. 376-377) observations in mind: 'Realistic evaluation is grounded on the belief that social interventions, such as quality improvement initiatives, are complex, and that the way they bring about change is influenced by, dependent on and in turn influences their contexts.' We adopted a multiple case study approach, focusing on eight MSK physiotherapy services in north-west England. Multiple case studies have been used to identify quality improvement patterns elsewhere in healthcare (Øvretveit and Klazinga, 2012) and in healthcare organisation and management innovations (Øvretveit et al., 2012). In a review of Lean changes in healthcare, Mazzocato et al., (2014, p.267) noted that most studies had concerned single cases:

it is difficult to know if variation in performance is due to the content of the lean changes, to the context of their application, to the process of implementation, or to interactions between the three ... Comparative multiple-case studies of lean applications could help clarify this knowledge gap.

Service improvement was monitored and evaluated at several points over 24 months and in different ways. The services were among 11 that were attempting different changes. We chose these eight services owing to the changes that were attempted; i.e., to introduce new routine follow-up appointment methods. Progress data were gathered at three meetings involving 11 service representatives over 15 months. Information was also gathered during two individual interviews with service representatives at six and ten months. Further information was gathered in three services after 12 months, through site visits and interviews. Additional follow-up interviews, after 24 months, with representatives sought progress and process information. On all occasions, information was sought about progress and about respondents' assessment of factors that enabled them to make progress, and factors that blocked or challenged them. Statistical data on progress was supplied by the information systems available to the teams, which varied from service to service.

Writing on research approaches to process changes in organisations, Langley (2009, p. 414) notes that, whilst retrospective data gathering can yield interesting results, 'there is nothing quite like being there in real time.' Having access to an ongoing change initiative 'is a golden opportunity to understand how the change will interact with its context'. Consent was given by all team members who contributed information during the research. We agreed that services would be anonymised and confidentiality terms were established. Formal research ethics approval was granted by the university employing the first author.

\section{The change}

The services on which we focus all aimed to reduce patient waiting times and reduce DNAs by introducing a new system for arranging routine follow-up appointments. This was the most common change explored in all 11 services involved in the network. In a traditional 
appointment system, a patient sees a physiotherapist for an initial assessment and perhaps some therapy or guidance is provided. In routine outpatient cases, the patient is given exercises designed to address their needs over time and to improve functionality and/or reduce pain. At the first appointment, before the patient leaves the clinic, a follow-up appointment is booked. An alternative approach is known as an 'opt-in' system; i.e., the patient is invited to make the follow-up appointment if s/he feels it's needed, within a certain time period following the initial meeting with the physiotherapist, after the patient has undertaken the recommended exercises. If they choose not to opt in during this period, they are discharged. In behavioural economic terms, this change to the system re-structures the decisions that the patient is asked to make. A similar approach has been taken to re-organise making a first therapy service appointment, where patients are encouraged to self-refer, rather than accessing services only through referral by a doctor (CSP, 2009; DH, 2008). Effects include:

- less wasted time for some patients, who might otherwise attend follow-up appointments they do not need;

- reduced DNA rates, because patients choose whether or not to take the initiative in making a follow-up appointment; those who do, are more likely to keep it;

- less wasted time for clinicians, because fewer appointment slots are lost to DNAs: clinicians are therefore more productive.

Consequently, we focus on practice in eight services that set out to make this change and on factors that appeared to affect the service. We discuss what lessons can be taken from the initiatives.

\section{Results}

Staff in eight services in the network attempted to introduce opt-in systems (coded as services A-H). Services covered different environments, urban, rural and mixed. Typically, they provided therapy at different sites within their catchment area. Services ranged from 12 to 31 whole time equivalent (WTE) therapists. The eight services took different approaches to implementing the change and achieved different results. Progress and outcome summaries appear in (Table I). Three other services in the network did not attempt to introduce opt-in systems: in one case this was because the appointment-booking system was centralised and the service manager thought that staff would not be able to manage opt-in bookings, nor was there any additional administrative support to set up an alternative system. In the other two cases, major changes to organisational systems and structures meant that service staff made no attempt to introduce changes during the project.

\section{Table I here}

\section{Progress and outcomes}

The services reported different results. Introduction and progress also varied between services. In $\mathrm{G}$ and $\mathrm{H}$, the change was not successfully introduced during the period that information was gathered. In six other services, the change was introduced, but the outcomes were not the same in each case. Dramatic reductions in DNAs were achieved in services A, B and $\mathrm{E}$, with smaller estimated reductions achieved in $\mathrm{C}, \mathrm{D}$ and $\mathrm{F}$. However, in $\mathrm{C}$ and $\mathrm{D}$, managers reported that other changes may have also reduced their DNAs. In B and E, changes quickly affected DNAs. In B, DNAs were half what they had been in the same period in the previous year (Table II). In E, the DNA rates dropped within a month to five unfilled appointments, compared with 27 in the same period the previous year. In the 
following month, they were five compared with 22 the previous year. In an ideal research project, easily comparable data would be available from all the services, but in these cases all statistical data on progress was supplied by the information systems available to the teams, and format varied from site to site.

\section{Table II here}

In A, however, there was little effect for three months and then the change had an effect (Table III). In C, there was no change in DNAs or waiting times for six months - but the team leader said that demand for therapy had increased during that time and was being met with no extra resources or waiting time increases, so perhaps the change was having an effect.

\section{Table III here}

It is not clear why these differences should have been experienced. However, service A staff introduced the change in a pilot area covering many patients, whereas in $\mathrm{B}$ and $\mathrm{E}$, each introduced the change in one clinic only. In B and E, DNA rates were initially higher than A and so logically there was more scope for improvement. In B and E, there was less scope for patients to revert to the old advanced booking system, whereas with services $\mathrm{A}$ and $\mathrm{C}$, patients could stop at the reception desk and make their next appointment on the way out. One unexpected outcome experienced in A and B was that waiting times for follow-up appointments were reduced, because appointments were not automatically booked for several weeks ahead. This meant that patients who chose to opt in were offered an appointment soon after they requested one and physiotherapists were more easily able to book follow-up appointments for more acute patients, who needed hands-on therapy, shortly after the first appointment. A further positive outcome was that, by increasing capacity, the change also reduced waiting time for new appointments. Another unexpected outcome reported in A, B and D was that the reduction in appointments lost to DNAs affected the time available to staff to undertake administrative tasks. Previously, some lost time had been used by clinicians for these tasks. Whilst the change improved productivity, some allowance had to be made to enable staff to complete their administrative tasks.

\section{Success factors}

Looking across the eight services, it is possible to suggest key success factors for the change. The most important factors appeared to be:

- clinician involvement and agreement

- communications system

- patient reactions

- IT

- no concurrent major organisational change

Clinician involvement and agreement was essential in services A-F, where the change was introduced and sustained. In $\mathrm{G}$ and $\mathrm{H}$, clinician reluctance or opposition led to the change being resisted or discontinued. In $\mathrm{B}$, where the pilot was extended to one additional site and where it was not successful, the team leader attributed this, in part, to unwilling clinical staff in the new location.

In all services where the change was introduced, clinical staff attitudes appeared to be affected by experiences elsewhere, accepting clinical reasoning behind using opt-in systems, 
professional body support for the system and accepting the need to solve pressing demand and high DNA problems. In A, for example, the staff were open to the opt-in system. Many were aware that opt-in systems were used elsewhere and the benefits managers claimed. They also knew that their service needed to reduce its DNA rates. Shortly after the change was introduced, the senior therapist who led the change said: 'So they were very open to it and very interested to see how it could work here. No one was resistant to it, but naturally they had concerns, which we were able to address.'

Communications systems was extended were important. The change required service staff to take patient telephone calls requesting appointments. Staff In eight services attempting to introduce the change, this was possible to arrange - even if only in the pilot site(s). Staff in one service said they would be unable to introduce this change as telephone calls were handled centrally where staff were unwilling to take on this extra workload. The service B manager said she thought that it would be difficult to spread the opt in system to all elinies in her service, because the centralised telephone booking system would not be able to accommodate this. The manager of service B said she thought that the centralised telephone booking system would not be able to accommodate the spread of the opt-in system to all clinics in her service.

Patients were a key factor influencing outcomes. A mixed reaction from patients was reported in $\mathrm{A}$ and $\mathrm{C}$, with some patients in both cases booking appointments in the traditional way. In A, this was thought to be linked to the patients being accustomed to booking appointments in advance. In $\mathrm{C}$, therapists continued to book one or two follow-up appointments in many cases, before moving to the opt-in system. Surveys carried out by staff in $\mathrm{A}, \mathrm{B}, \mathrm{C}$ all three services and in $\mathrm{F}$ found that most opt-in patients were satisfied with treatment and that, where they had not opted for further treatment, most had taken this decision because they thought their self-management plan was effective. In the pilot site B, staff took a particularly positive approach to explaining the change to patients, emphasising therapeutic exercises and the need for patients to make further appointments only if or when they judged the time was right.

The IT systems available to service staff varied greatly; e.g., staff in A, B and D were able to call on real time DNA and waiting time data, but $\mathrm{C}$ staff had no such facility. Where good systems were available, they enabled service managers or team leaders to quickly identify where any problems were occurring and also to monitor the change's effect. Major changes to systems and structures affected two services; staff said they were unable to introduce change at the start. Major changes also later affected E, where therapy services were put out to tender and the contract awarded to a private healthcare company that discontinued the opt-in system. For other services, relative stability appeared an important factor in enabling the changes to take place.

\section{Leading and managing the change}

Where services were successful in implementing this change, certain key actions were carried out by most/all teams:

- seeking information and advice from elsewhere: in all teams that implemented the change, some information and advice was sought from staff working in other services who had successfully implemented the change. This enabled therapists to satisfy their concerns about the change's clinical value. The CSP's (i.e., the professional body) support was also a factor in satisfying concerns.

- agreeing protocols: staff in all services developed protocols for the new system. To manage the risk that any patient would be disadvantaged, staff in all services established guidelines about which patients would not be suitable for the opt-in system, including 
those who might not be able to make an informed decision about whether to seek a further appointment. To a greater or lesser extent, in each service, individual physiotherapists were able to make decisions within these guidelines about whether to use opt-in or to book appointments for individual patients.

- timely adjustments: piloting the change was important in A and C. In A, the pilot was defined large geographically. In $\mathrm{C}$, the pilot was carried out by more senior physiotherapists. In both cases, this improved acceptance by therapists. In B, the system was introduced opportunistically, in response to a problem in one clinic. The success at that clinic prompted experiments in other sites. In all three cases, adjustments were made to the system during the pilot phase.

\section{Discussion}

The intervention in this research was relatively small in comparison to system-wide changes seen in many quality improvement programmes (Burgess and Radnor, 2013), but with a potentially powerful effect. The small scale and the intervention's containment meant that the change could be implemented without seeking full stakeholder cooperation from a large number of stakeholders. The key groups were clinicians in the therapy teams, patients and in some cases administrative staff. Introducing opt-in systems for routine follow-up appointments re-structured the choices facing patients. Re-structuring can significantly reduce the numbers of total patients who did not attend appointments and thus improve productivity, and reduce waiting times for routine appointments. However, the interventions had different effects in different services - possibly owing to differences in how the changes were introduced and implemented, and contextual factors, such as C's increasing referrals.

Two key principles, already established elsewhere, were borne out in our sites: (i) changes require clinician support if they are to be effective (Abdallah, 2014; Sanders et al., 2014); and (ii) outcomes are influenced by context (Khatami and Rosengren, 2015; Walshe, 2007). The most critical conditions for success in our research were that there was buy-in and action from clinicians, that patients were willing to cooperate and that the communication systems were able to support the change. Earlier research on changes in healthcare systems show that context affects success, and that an evaluation should seek to 'establish when, how and why the intervention works' (Walshe, 2007, p.58). Certain influential factors are evident in these cases.

A key mechanism for reducing DNAs and waiting times, was the change in choice and behaviour among some patients in each service. The behaviour change, on which behavioural economics focuses (Loewenstein et al., 2012; Martin et al., 2012), is in this context, the greater likelihood that patients will attend appointments that they make on their own initiative. Patients appeared to react best to this when the system was explained as being integral to their therapy (as in service B) and they were not accustomed to other appointment systems. It is possible that different patient groups in each case affected the intervention. Studying physiotherapy appointment DNAs in one hospital, French et al., (2005) found that older patients were more likely to attend appointments. However, no demographic data on patients was systematically gathered in our case study sites; a suitable future research focus.

The therapists' involvement and agreement was influenced by the clinical case for this intervention as a means to tackling a situation that was agreed to be problematic. The clinical case was aided by the professional body's support and by accounts from other teams who had introduced a similar change, and by establishing an agreed protocol to safeguard vulnerable patients, and to preserve professional autonomy. In all cases, some adjustments were made to the way the new systems worked in each service based on experience: as Øvretveit et al., 
(2012, p. 246) remarked in different case studies, it was important to enable 'regular reviews and re-planning of the implementation'. Piloting and adjusting are advocated by process improvement and service improvement methods (Health Foundation, 2013; NHS III, 2005). The need for adjustments would be expected by researchers such as Walshe (2009) and Sanders et al., (2014), with their emphasis on contextual influence and on tools and techniques.

The communications infrastructure for making routine appointments was central to the change; in two cases, no suitable system was cited by service staff as an insurmountable obstacle to adopting the intervention; in one other case the service manager believed it would limit extension beyond the pilot site. A third influential factor appeared to be IT systems providing prompt data.

\section{Conclusions}

These case studies show that changing the appointments system for routine follow-up therapy can reduce the total patients who do not attend appointments and subsequently reduce waiting times for new and for follow-up appointments. At a time when services are under pressure from rising demand and shrinking budgets, this is a significant finding. However, these results are not guaranteed and appear to depend at least in part on how the new system is explained to patients. There may also be other contextual factors that affect the change's effect. How quickly improvements were achieved also varied between the cases and some adjustments were necessary to the plans for change in all cases. Clinical and administrative staff's active cooperation was essential to the change. Factors that appeared to be important in engaging staff were:

- The system could benefit patients.

- It was being used in other services elsewhere, with good results.

- The professional body supported the system.

- There were acknowledged problems with the current working methods.

- Acceptable guidelines were developed as to when and to whom the new system would apply, which allowed some scope for exercising individual clinical judgement.

It appears likely that, where the conditions for introducing this change exist, or can be cultivated, it will benefit other therapy service providers, with the proviso that context affects the outcomes and, therefore, it is appropriate to take an approach that which acknowledges the importance of that careful experimentation and learning are important.

\section{References}

Abdallah, A. (2014), 'Implementing quality initiatives in healthcare organizations: drivers and challenges', International Journal of Health Care Quality Assurance, Vol. 27 No. 3, pp. $166-181$.

Al-Balushi, S., Sohal, A.S., Singh, P.J., Al Hajri, A., Al Farsi, Y.M. and Al Abri, R. (2014), 'Readiness factors for lean implementation in healthcare settings-a literature review', Journal of Health Organization and Management Vol. 28 No. 2, pp. 135-153. 
Amlani, N. (2011), 'Self-Referral to Physiotherapy with 'Same Day' Advice, Triage and Signposting', available at $<\mathrm{http}$ //chain.ulcc.ac.uk/chain/documents/AHPprojectNavroz AmlaniLincolnshireFINALv3.doc >, accessed April 2016.

Appleby, J., Thompson, J. and Jabbal, J. (2014), 'How is the NHS performing?' Quarterly monitoring report, July, King's Fund, London.

Aveling, E-L., Martin, G., Armstrong, N., Banerjee, J. and Dixon-Woods, M. (2012), 'Quality improvement through clinical communities: eight lessons for practice', Journal of Health Organization and Management Vol. 26 No. 2, pp. 158-174.

Batalden, P.B. and Davidoff, F. (2007), 'What is 'quality improvement' and how can it transform healthcare?' Quality and Safety in Health Care, Vol. 16 No. 1, pp. 2-3.

Boak, G., Dickens, V., Newson, A. and Brown, L. (2015),'Distributed leadership, team working and service improvement in healthcare', Leadership in Health Services, Vol. 28 Iss 4, pp. 332- 344.

Brandao de Souza, L. (2009), 'Trends and approaches in lean healthcare', Leadership in Health Services, Vol. 22 No. 2, pp. 121-139.

Burgess, N. and Radnor, Z. (2013), 'Evaluating Lean in healthcare', International Journal of Health Care Quality Assurance, Vol. 26 No. 3, pp. 220 - 235.

Clews, G. (2013), 'Self-referral halves DNA rates', Frontline 1 May pp. 19-21 available at $<$ http://www.csp.org.uk/frontline/article/self-referral-halves-dna-rates $>$, accessed April 2016.

CSP. (2013), Physiotherapy outpatient services survey 2012, Chartered Society of Physiotherapy, London, available from <http://www.csp.org.uk>, accessed April 2016.

CSP. (2009), Self-Referral: Implementation Tools, Chartered Society of Physiotherapy, London.

DH. (2008), Self-referral pilots to musculoskeletal physiotherapy and the implications for improving access to other AHP services, Department of Health, London.

DH. (2011), Allied Health Professions (AHP) Service Improvement Project, Final Report, Department of Health, London, available from <http://www.dh.gov.uk>, accessed April 2016.

Dorning, H. and Bardsley, M. (2014), Focus on: Allied health professionals: Can we measure quality of care? The Health Foundation and the Nuffield Trust, London, available from $<$ www.qualitywatch.org.uk>, accessed April 2016.

Drotz, E. and Poksinska, B. (2014), 'Lean in health care from employees' perspectives', Journal of Health Organization and Management, Vol. 28 No. 2, pp. 177-195.

El-Tantawy, C., DiRe, A. and Frare, G. (2000), 'The challenge of managing patient cancellation and non-attendance in an outpatient physiotherapy clinic', Physiotherapy Canada, December, Vol. 52 No. 2, pp163-7.

Foote, J.L., North, N.H. and Houston, D.J. (2004), 'Towards a systemic understanding of a hospital waiting list', Journal of Health Organization and Management, Vol. 18 No. 3 , pp. 140-154.

French, H., McGrane, E. and Cooke, G. (2005), 'A prospective study of non-attendance to a physiotherapy outpatient department', Physiotherapy Ireland, Vol. 26 Iss. 1, pp. 16-22.

Gauld, G., Burgers, J., Dobrow, M., Minhas, R., Wendt, C., Cohen, A.B. and Luxford, K. (2014), 'Healthcare system performance improvement', Journal of Health Organization and Management, Vol. 28 No. 1 pp. 2 - 20. 
Gijo, E.V., Antony, J., Hernandez, J. and Scaria, J. (2013), 'Reducing patient waiting time in a pathology department using the Six Sigma methodology', Leadership in Health Services, Vol. 26 No. 4, pp. 253-267.

Gollop, R., Whitby, E., Buchanan, D. and Ketley, D. (2004), 'Influencing sceptical staff to become supporters of service improvement: a qualitative study of doctors' and managers' views', Quality and Safety in Health Care, Vol. 13, pp.108-114.

Ham, C., Kipping, R. and McLeod, H. (2003), 'Redesigning Work Processes in Health Care: Lessons from the National Health Service', The Milbank Quarterly, Vol. 81 No. 3, pp. 415-439.

Harding, P. (2011), 'Improve MSK Therapy Services by self-referral, condition specific pathways and reduced waits', available at $<$ http://chain.ulcc.ac.uk/chain/documents/ AHPprojectPatrickHardingBarnesFINAL.doc>, accessed April 2016.

Health Foundation. (2011), Safer Patients Initiative, The Health Foundation, London.

Health Foundation. (2013), Improving Patient Flow, The Health Foundation, London.

Holt, T.A., Thorogood, M., Griffiths, F., Munday, S., Friede, T. and Stables, D. (2010), 'Automated electronic reminders to facilitate primary cardiovascular disease prevention: randomised controlled trial', British Journal of General Practice, April, pp. e137-e143 DOI: 10.3399/bjgp10X483904

Hwang, P., Hwang, D. and Hong, P. (2014), 'Lean practices for quality results: a case illustration', International Journal of Health Care Quality Assurance, Vol. 27 Iss. 8, pp. $729-741$.

IHI. (2005), Going Lean in Healthcare, Institute of Healthcare Improvement, Cambridge, MA.

Jones D. and Mitchell, A. (2006) Lean thinking for the NHS, NHS Confederation, London.

Joosten, T., Bongers, I. and Janssen, R. (2009), 'Application of lean thinking to health care: issues and observations', International Journal for Quality in Health Care, Vol. 21 No. 5, pp. 341-347.

Kaplan, R.S. and Porter, M.E. (2011), 'How to Solve the Cost Crisis in Health Care', Harvard Business Review, September, pp. 47-64.

Khatami, A. and Rosengren, K. (2015), 'An improvement project within urological care', International Journal of Health Care Quality Assurance, Vol. 28 No. 4, pp. 412 - 422.

Langley, A. (2009), 'Studying Processes in and Around Organizations', in Buchanan, D. and Bryman, A. (Eds.), The Sage Handbook of Organizational Research Methods, Sage, London, pp.409-429.

Langley, A. and Denis, J-L. (2011), 'Beyond evidence: the micropolitics of improvement', Quality and Safety in Health Care, Vol. 20 (Suppl. 1), pp. i43-i46.

Liu, P.J., Wisdom, J., Roberto, C.A., Liu, L.J. and Ubel, P.A. (2014), 'Using Behavioral Economics to Design More Effective Food Policies to Address Obesity', Applied Economic Perspectives and Policy, Vol. 36 No. 1, pp.6-24.

Locock, L. (2003), 'Healthcare redesign: meaning, origins and application', Quality and Safety in Health Care, Vol. 12, pp. 53-57.

Lodge. A. and Bamford, D. (2007), 'Health service improvement through diagnostic waiting list management', Leadership in Health Services, Vol. 20 No. 4, pp. 254-265.

Loewenstein, G., Asch, D.A., Friedman, J.Y., Melichar, L.A. and Volpp, K.G. (2012), 'Can behavioural economics make us healthier?' British Medical Journal, Vol. 344, p. e3482. 
Martin, S.J., Bassi, S. and Dunbar-Rees, R. (2012), 'Commitments, norms and custard creams- a social influence approach to reducing did not attends (DNAs)', Journal of the Royal Society of Medicine, No. 105, pp. 101-104.

Mazzocato, P., Savage, C., Brommels, M., Aronsson, H. and Thor, J. (2010), 'Lean thinking in healthcare: a realist review of the literature', Journal of Quality and Safety in Health Care, Vol. 19, pp. 376-382.

Mazzocato, P., Thor, J., Backman, U., Brommels, M., Carlsson, J., Jonsson, F., Hagmar, M. and Savage, C. (2014), 'Complexity complicates lean: lessons from seven emergency services', Journal of Health Organization and Management, Vol. 28 No. 2, pp. 266288.

McIntosh, B., Sheppy, B. and Cohen, I. (2014), 'Illusion or delusion - Lean management in the health sector', International Journal of Health Care Quality Assurance, Vol. 27 No. 6, pp. $482-492$.

Modernisation Agency. (2004), 10 High Impact Changes for Service Improvement and Delivery, NHS Modernisation Agency, Coventry.

NHS III. (2005), Process mapping, analysis and redesign, NHS Institute for Innovation and Improvement, Coventry.

Øvretveit, J. (2004), 'A framework for quality improvement translation: understanding the conditionality of interventions', Joint Commission Journal on Quality and Safety, Global Supplement, pp. 15-24.

Øvretveit, J., Andreen-Sachs, M., Carlsson, J., Gustafsson, H., Hansson, J., Keller, C., Lofgren, S., Mazzocato, P., Tolf, S. and Brommels. M. (2012), 'Implementing organisation and management innovations in Swedish healthcare: Lessons from a comparison of 12 cases', Journal of Health Organization and Management, Vol. 26 No. 2, pp. 237-257.

Øvretveit, J. and Klazinga, N. (2012), 'Learning from large-scale quality improvement through comparisons', International Journal for Quality in Health Care, Vol. 24 No. 5, pp. 463-469.

Pawson, R. and Tilley, N. (1997) Realistic Evaluation, Sage, London.

Porter, M.E. and Lee, T.H. (2013) 'The strategy that will fix healthcare', Harvard Business Review, Vol. 91 No. 10, pp. 51-70.

Powell, A.E., Rushmer, R.K. and Davies, H.T.O. (2009), A systematic narrative review of quality improvement models in health care, NHS Quality Improvement Scotland, Edinburgh.

Radnor, Z.J., Holweg, M. and Waring, J. (2012), 'Lean in healthcare: The unfilled promise?' Social Science and Medicine 74, pp. 364-371.

Robinson, J. (2011), 'Self-Referral to Physiotherapy for Musculoskeletal Conditions: initially with Drayton Practice, then with a view to extend across Portsmouth's remaining 28 practices', available at <http://chain.ulcc.ac.uk/chain/documents/AHPproject JoannaRobinsonSolent.doc $>$, accessed April 2016.

Robson, C. (2011), Real World Research, Wiley, London.

Sanders, T., Ong, B.N., Sowden, G. and Foster, N. (2014), 'Implementing change in physiotherapy: professions, contexts and interventions', Journal of Health Organization and Management, Vol. 28 No. 1, pp. 96-114.

Thorlby, R. and Maybin, J. (2010), A High-Performing NHS? A review of progress 19972010, King's Fund, London. 
Walshe, K. (2007), 'Understanding what works - and why-in quality improvement: the need for theory-driven evaluation', International Journal for Quality in Health Care, Vol.19 No. 2, pp. 57-59.

Walshe, K. (2009), 'Pseudoinnovation: the development and spread of healthcare quality improvement methodologies', International Journal for Quality in Health Care, Vol. 21 No. 3, pp. 153-159.

Waring, J.J. and Bishop, S. (2010), 'Lean healthcare: Rhetoric, ritual and resistance', Social Science and Medicine, Vol. 71, pp. 1332-1340.

WHO. (2009), The European health report 2009: health and health systems, World Health Organization, Geneva.

WHO. (2012), Health in the Americas, World Health Organization, Geneva.

Young, T.P. and McClean, S.I. (2009), 'Some challenges facing Lean Thinking in healthcare', International Journal for Quality in Health Care, Vol. 21 No. 5, pp. 309310.

Table I: Services attempting to implement opt-in systems and their outcomes

\begin{tabular}{|c|c|c|}
\hline Service & Attempted opt-in systems & Outcome \\
\hline A & $\begin{array}{l}\text { An initial pilot in the service was } \\
\text { followed by the system being rolled } \\
\text { out to the whole team }\end{array}$ & $\begin{array}{l}\text { Little effect on DNAs for three months, } \\
\text { then a significant reduction (from } 11 \% \\
\text { to } 5 \% \text { ) }\end{array}$ \\
\hline $\mathrm{B}$ & $\begin{array}{l}\text { Piloted in one clinic successfully; } \\
\text { attempted in two other clinics, with } \\
\text { success in one but not in the other }\end{array}$ & $\begin{array}{l}\text { In the first clinic, DNAs fell from over } \\
20 \% \text { to under } 10 \% \text {; there was a fall in } \\
\text { waiting times from five to one to two } \\
\text { weeks }\end{array}$ \\
\hline $\mathrm{C}$ & $\begin{array}{l}\text { Piloted by senior clinicians and then } \\
\text { all the therapists asked to use opt-in }\end{array}$ & $\begin{array}{l}\text { No impact on DNAs or waiting times } \\
\text { after six months; after a further } 11 \\
\text { months, DNAs declined from } 14 \% \text { to } \\
10 \% \text { - but other changes may have } \\
\text { influenced outcomes }\end{array}$ \\
\hline $\mathrm{D}$ & $\begin{array}{l}\text { Introduced opt-in along with other } \\
\text { changes to the service, including } \\
\text { changing team structures and work } \\
\text { flows }\end{array}$ & $\begin{array}{l}\text { Service manager thought that opt-in } \\
\text { had reduced DNAs by } 3-4 \% \text {, but other } \\
\text { changes to the service may have } \\
\text { influenced outcomes }\end{array}$ \\
\hline $\mathrm{E}$ & $\begin{array}{l}\text { Introduced in one small clinic, } \\
\text { where DNAs were high and waiting } \\
\text { times were long. Team leader } \\
\text { thought it could not be rolled out to } \\
\text { other clinics owing to a central } \\
\text { appointment-booking service }\end{array}$ & $\begin{array}{l}\text { DNAs reduced to five per two-month } \\
\text { period, compared to over } 20 \text { in the } \\
\text { previous year }\end{array}$ \\
\hline $\mathrm{F}$ & Introduced into the whole service & $\begin{array}{l}\text { Estimated effect was to reduce DNAs } \\
\text { from } 4.5 \% \text { to } 3 \%\end{array}$ \\
\hline G & $\begin{array}{l}\text { Opt-in was tried as an experiment } \\
\text { by two senior clinicians. Service } \\
\text { manager reported that staff were } \\
\text { doubtful about its effects and it was } \\
\text { discontinued }\end{array}$ & $\begin{array}{l}\text { No reported effect on DNAs or waiting } \\
\text { times during trial period }\end{array}$ \\
\hline
\end{tabular}


Table II: DNAs at one site in Service B: change introduced in January Year 1, DNAs compared to the same months in the preceding year

\begin{tabular}{|lcccccccc|}
\hline$\%$ & Jan & Feb & Mar & Apr & May & June & July & Aug \\
\hline Year 1 & 17.5 & 9.4 & 10.4 & 8.6 & 6.3 & 9.6 & 7.7 & 10.9 \\
\hline $\begin{array}{l}\text { Prior } \\
\text { year }\end{array}$ & 22.1 & 24.3 & 21.3 & 19.4 & 25.4 & 18.7 & 20.2 & 18.3 \\
\hline
\end{tabular}

Table III: DNAs in Service A

\begin{tabular}{|rllllll|}
\hline \multicolumn{6}{|c|}{ DNA rate measured in ten week periods before (-1) and after opt-in } \\
\hline Period -1 & 1 & 2 & 3 & 4 & 5 & 6 \\
\hline $11 \%$ & $11 \%$ & $10 \%$ & $9 \%$ & $8 \%$ & $5 \%$ & $5 \%$ \\
\hline
\end{tabular}

